\title{
THE IMPORTANCE OF JOB AUTONOMY AS A DRIVER OF ORGANIZATIONAL COMMITMENT THROUGH WORK - LIFE BALANCE FOR EMPLOYEES IN A LIFE INSURANCE COMPANY
}

\author{
Andreas Reza*)1, Rina Anindita*) \\ ${ }^{*}$ Master of Management Study Program, Universitas Esa Unggul \\ Jl. Arjuna Utara No.9, Kebon Jeruk, Jakarta 11510, Indonesia, Indonesia
}

\begin{abstract}
This study aimed to figure out the effects of job autonomy, work-life balance, organizational commitment and job satisfaction as mediating variables. This research was conducted with a survey using a digital questionnaire distributed in June-July 2020 to 170 employees who work in the life insurance industry. Data were analyzed using the Structural Equation Model (SEM). This study showed that good job autonomy increased work-life balance. It also increased job satisfaction. Good work-life balance increased job satisfaction and good work-life increased organizational commitment through job satisfaction.
\end{abstract}

Keywords: job autonomy, job satisfaction, life insurance industry, organizational commitment, work-life balance

\begin{abstract}
Abstrak: Penelitian ini bertujuan menguji pengaruh Otonomi Kerja, Work-Life Balance, Komitmen Organisasional dengan Kepuasan Kerja sebagai variabel pemediasi. Penelitian ini dilakukan dengan survey menggunakan kuesioner secara digital yang disebarkan pada bulan Juni-Juli 2020 dimana responden yang digunakan sebanyak 170 karyawan yang bekerja di industri asuransi jiwa . Data dianalisis dengan menggunakan Structural Equation Model (SEM). Hasil penelitian ini menunjukkan bahwa otonomi kerja yang baik akan meningkatkan work -life balance, otonomi kerja yang baik akan meningkatkan kepuasan kerja, work -life balance yang baik akan meningkatkan kepuasan kerja, work - life balance yang baik akan meningkatkan komitmen organisasional melalui kepuasan kerja,
\end{abstract}

Kata kunci: otonomi kerja, kepuasan kerja, industri asuransi jiwa, komitmen organisasional, work-life balance

${ }^{1}$ Corresponding author:

Email: reza.loing@gmail.com 


\section{INTRODUCTION}

Every company wants its employees to feel happy and satisfy with their work, and perform well. To do so, it is important for the company to give job autonomy to the employees. It will improve work performance and provide positive results for the company. An employee with high job autonomy will feel trusted to do the job. It will create a positive impact on the employee's selfmotivation and effectiveness at work. Job autonomy defines how far a work provides substantial freedom, independence, and flexibility to individuals in scheduling work and in determining the procedures used in carrying it out (Saragih, 2011 in Sugiyarti and Meiliana, 2018).

Work-life balance is a balanced state on two demands: work and personal life. In the employee's perspective, work-life balance is considered to be the choice of managing work and personal obligations or responsibility to family. While in the company's perspective, work-life balance is a challenge to create a supportive culture in the company, where employees can focus on the job and feel comfortable in their workplace. But in general, employees find it difficult to set a balanced time between work and their personal life. It is usually due to the task deadline set by the company that makes employees to finish the work more than the specified hours. It shows that work-life balance in a company is very important. The company must pay attention to the balance proportion between the personal life and working life, so the employees will feel comfortable at work and increase productivity as a result (Asepta and Maruno, 2017).

Stefanovska et al. (2019) shows that work-life balance has a significant positive correlation with job satisfaction. She suggests that the manager's behavior towards employees will determine the support or obstacles. In another study, Wenno (2018) states that work-life balance has a positive correlation with job satisfaction in employees working in a State-Owned Enterprise. He states that the employees who can manage worklife balance can achieve higher job satisfaction and contribute more to the company's success.Similarly, Varatharaj and Vasantha (2016) research identifies work-life balance as a source of job satisfaction in the service sector.

Gulbahar et al. (2014) shows that there is a positive and significant correlation between work-life balance and organizational commitment. Similarly, Sakthivel and Jayakrishnan (2012) also states that work-life balance and organizational commitment have a positive correlation. Employees with good work-life balance will be more committed to the organization. Organizations should treat their employees as clients and actively strive to increase employee commitment and job satisfaction, as well as reducing causes of stress both in the workplace and personal life through worklife balance policies.

Studies on job autonomy, work-life balance, job satisfaction, and organizational commitment have been widely carried out. But, many of them have not yet examined the correlation between job autonomy and work-life balance and organizational commitment. This research was conducted in a life insurance company that provides various insurance products such as life insurance, healthcare, pension, education plan, and sharia life insurance. This company is very dynamic in meeting the needs of each customer to get the best benefits and protection.

The competition in this industry demands employees to work more smartly, creatively, and quickly adapt to the change. With this work-life balance program, the company must support the employees to be more vibrant and productive. The authors conducted a study in one of the life insurance companies where the work-life balance program and the job autonomy are considered to be less applied. The program already exists, but it seems to be not well-developed, considering now we live in the Digital Age 4.0. In the last three years, there are only small numbers of research connecting job autonomy and work-life balance for employees in the life insurance industry. Based on these gaps, this study will show the effect of work autonomy and work-life balance with organizational commitment through employee satisfaction that can provide positive feedback in the research area.

\section{METHODS}

Structural Equation Model (SEM) requires a minimum number of samples to be five times greater than the number of samples analyzed (Hair et al. 2019). As there were 38 statements in this research questionnaire, the sample size required is 170 respondents to research work autonomy, work-life balance, job satisfaction, and organizational commitment. The data used in 
this study using primary data specifically collected to answer directly from charging the questionnaire by respondents. The result of the primary data processing in form of quantitative data by using likert scale and a judgment scoring use numbers one to five which is code to find out high and which is more low. The assessment of starts from strongly disagree with the lowest weight and totally agree with the weights highest (Manihuruk and Soehari, 2020). The research was conducted at Life Insurance Company located in West Jakarta in June 2020 with respondents being employees who work at the company.

In this study, there were exogenous variables and endogenous variables. Exogenous variables consisted of job autonomy and work-life balance. Endogenous variables consisted of job satisfaction and organizational commitment. Job autonomy variables were measured using dimensions from Breaugh, 1985 in Pearson et al. (2009) consisting of three autonomy aspect assessment scales: work method, work schedule, and work criteria. To measure the variables of work-life balance, dimension from Hudson (2005) was used. It consisted of time balance, involvement balance, and satisfaction balance. Then, the job satisfaction variables were measured by using dimensions consisting of job satisfaction, satisfaction with rewards or salaries, satisfaction with supervisory supervision, satisfaction with co-workers, and promotional opportunities (Robbins and Judge, 2013). The organizational commitment variables were measured using dimensions from Meyer et al. (1993) including affective commitments, ongoing commitments, and normative commitments. The dimensions of measurements displayed in the form of the questionnaire were first tested for validity and reliability.

To did the validity test, Confirmatory Factor Analysis was used by looking at Kaiser-Meyer-Elkin value and Measures of Sampling Adequacy (MSA). In this test, the value obtained should be greater than 0.5 which meant that the factor analysis was appropriate and could be processed. The scale of work autonomy consisted of 3 valid questions, the work-life balance scale consisted of 8 valid questions, the job satisfaction scale consisted of 10 valid questions, and the organizational commitment scale consisted of 8 valid questions. Reliability tests on all indicators of work autonomy, work-life balance, job satisfaction, and organizational commitment showed alpha Cronbach was greater than 0.5 which meant reliable (Malhotra, 2010), and those indicators could be considered to be reliable as data collection tools. The stage after was data processing using SEM (Structural Equation Modelling) analysis method that explains the attachment of variables complexly, and the direct or indirect effects of one or more variables to another (Hair et al. 2010)

\section{Hypothesis Development}

The Relationship of Job Autonomy to Work-Life Balance

Handayani et al. (2018) explains that job autonomy is an aspect that plays an important role in achieving work-life balance. Job autonomy allows employees to make decisions and flexibility to manage workloads to minimize stress, fatigue, and conflict (Ahuja et al. 2007 in Handayani et al. 2018). This can help someone to reduce the conflict between work and family. Thus, it will be easier for employees to use their time for work and for the family. (Prameaux et al. 2007 in Handayani et al. 2018). Based on this research, here is the hypothesis that can be submitted:

H1 : Appropriate job autonomy will improve work-life balance.

The Relationship of Job Autonomy to Job Satisfaction

Sugiyarti and Meiliana (2018) explain that job autonomy increases job satisfaction because employees feel being trusted to do the tasks. This autonomy will make them more motivated so that they feel satisfied and more committed, and they will make more efforts to learn, develop, and grow Hakim and Septarini (2014) also explain that job satisfaction is a state of happiness at work. This autonomy can increase job satisfaction because it can create positive responses. An autonomous worker will have the opportunity to achieve the goals and intrinsic values, such as selfdevelopment, relationships, and community. By receiving those benefits, the employees are supposed to feel satisfied and happy about their work (Ryan et al. 2008 in Hakim and Septarini, 2014). Based on this research, here is the hypothesis that can be submitted: $\mathrm{H} 2$ : Appropriate job autonomy can increase job satisfaction. 
The Relationship of Work - Life Balance to Job Satisfaction

Saad and Sumaiti (2010) state that when the company provides work-life balance for its employees, so they can manage a balanced time between their personal life and work, the productivity will grow and can contribute more to the company. Wenno (2018) in his research also states that employees will gain more job satisfaction as they can manage a balanced time between work and other commitments such as family, hobbies, art, and studies. This is one of the factors that affect job satisfaction. On the other hand Varatharaj and Vasantha (2016) state that work-life balance is a source of job satisfaction in industrial sectors such as banking, education, and government organizations. They say that employees who manage a work-life balance can achieve higher job satisfaction and contribute more to the organization. That research shows that work-life balance, where employees appreciated and recognized, can increase job satisfaction. Stefanovska et al. (2019) in research on the variables of work-life balance and job satisfaction conducted in manufacturing companies shows that work-life balance has a positive impact on job satisfaction. In line with that, it is suggested that the manager's behavior towards employees also determines the support or obstacles in the company. Based on this research, here is the hypothesis that can be submitted : H3 : Appropriate Work- life balance can increase job satisfaction

The Relationship of Work - Life Balance to Organizational Commitment

Parkes and Langford (2008) in Rene and Wahyuni (2018) define work-life balance as an individual's ability to meet their work and family commitments, as well as non-employment responsibilities and other activities. Work-life balance which contributes to employee engagement can provide job satisfaction and organizational commitment. As a result, it will contribute to higher productivity and lower organizational turnover (Parkes and Langford 2008 in Rene and Wahyuni, 2018). Gulbahar et al. (2014) states that there is a positive and significant relationship between worklife balance and organizational commitment. Research conducted by Sakthivel and Jayakrishnan (2012) found that work-life balance and organizational commitment have a positive relationship. Employees who have a good work-life balance will be more committed to the organization. On the other hand, the organization should treat their employees as clients and actively strive to increase employee commitment and job satisfaction, as well as to reduce the source of stress in both the workplace and family life through this work-life balance strategy. Based on these studies the hypothesis that can be submitted:

H4 : Appropriate Work-life balance can increase organizational commitment.

The Relationship of Job Satisfaction to Organizational Commitment

Rojuaniah (2017) explains that job satisfaction affects organizational commitment. This indicates that the higher the job satisfaction they get, the higher their commitment to the work. If an organization provides salaries and workloads that fit the duties, leaders who can encourage the work of employees, and colleagues who can establish high cooperation, then it will increase the commitment to the organization. Taurisa and Ratnawati (2012) state that job satisfaction has a close relationship with organizational commitment. Job satisfaction is the first aspect achieved before employees have an organizational commitment. According to Gunlu and Aksarayli (2010) job satisfaction has a significant effect on organizational commitment. Various indicators of job satisfaction such as satisfaction with salary, coworkers, supervision and employment have positive and affect significantly to organizational commitment. When the needs of employees are met, then there is likely to be an increase in dedicated organizational (Malik et al. 2010 in Meria, 2018). Job satisfaction has a significant effect on organizational commitment. Various indicators of job satisfaction such as satisfaction with salary, co-workers, supervision, and employment have positive and affect significantly to organizational commitment. When the needs of employees are met, then there is likely to be an increase in dedicated organizational commitments. Based on the research such research hypotheses can be submitted:

H5 : Appropriate job satisfaction can increase organizational commitment

From the explanation of each hypothesis, the research model can be described as follow (Figure 1). 


\section{RESULTS}

In the results of the construct validity measurement, all indicators on the job autonomy variable and organizational commitment were acceptable, as the loading factor value has a good match $(>0.50)$, and the $\mathrm{t}$-value was greater than the $\mathrm{t}$-table (1.96) at a significant level of $5 \%$. Furthermore, the construct reliability test qualifies for reliability with a $\mathrm{CR}$ value above 0.60 and a VE value above 0.50 (Hair et al. 2019). At the $C R$ value, all eligible variables valued above 0.60 , job autonomy (0.74), work-life balance (0.89), job satisfaction (0.93), and organizational commitment (0.92)(Table 1$)$.

Researchers wanted to focus on the effect of work autonomy on work-life balance, work autonomy on job satisfaction, work-life balance on job satisfaction, work-life balance on organizational commitment, and job satisfaction to organizational commitment. From all the hypotheses submitted, the results showed that all data support the hypotheses based on the following T-Value Path Diagram (Figure 2). Based on Path Diagram T-Value, then the hypothesis in this research is presented in the Table 2 .

In this study, some results showed that good job autonomy can improve the work-life balance of employees in the life insurance industry. This means, job autonomy is one of the various characteristics of work that plays an important role in achieving worklife balance. When employees are granted autonomy in work it will make it easier for employees to manage time for work and time for family. This result is supported by Handayani et al. (2018) statement that job autonomy has a significant role in achieving work-life balance.
Some results also showed that good job autonomy would increase job satisfaction of the employee working in the life insurance industry. This means, good job autonomy can improve the level of the job satisfaction. Employees who have job autonomy become more motivated, more satisfactied, and more committed and serious in learning, developing and growing. This result is supported by the statement of Sugiyarti and Meiliana (2018) and Hakim and Septarini (2014) that good work autonomy can improve job satisfaction.

Some results also indicated that a good work-life balance would increase employee job satisfaction in the life insurance industry. This means that a good worklife balance can increase employees' work productivity and contribute more to the company. Employees with a good work-life balance can manage time for family and work by using flexible working hours, which is one of the factors that can affect job satisfaction. This is supported by Saad and Sumaiti (2010); Wenno (2018); Stefanovska-Petkovska et al. (2019) which states that a good work-life balance can improve employee job satisfaction.

This research also showed that employees with work-life balance can increase their organizational commitment to the life insurance industry they work in. This means that the organization that treats its employees as clients will actively strive for them to be more committed and reduce the source of stress, both in the workplace and family life. This work-life balance contributes to employee engagement including commitments to the company that can contribute to higher productivity of the company. This is supported by the statement of Gulbahar et al. (2014); Sakthivel and Jayakrishnan (2012); and Rene and Wahyuni (2018) which states that with the absence of work-life balance can increase organizational commitment.

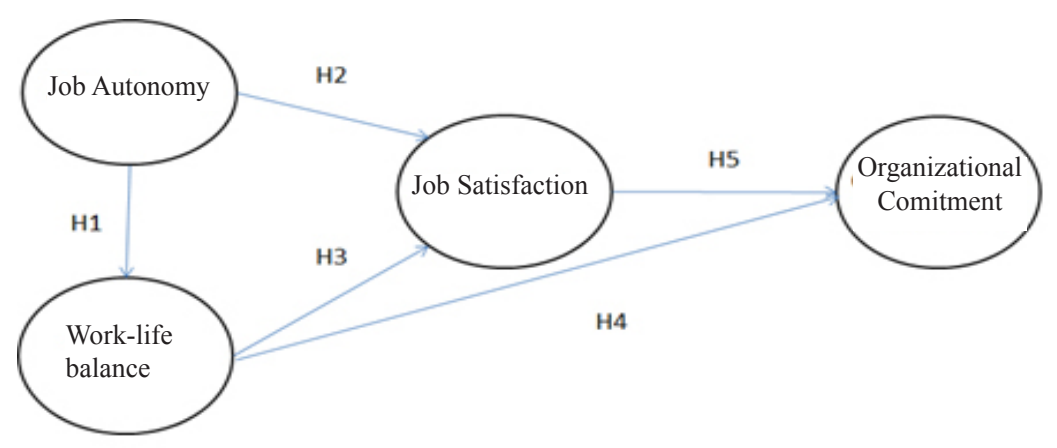

Figure 1. Research model 
Table 1. Calculation results of construct realibility and variance extraced

\begin{tabular}{|c|c|c|c|c|c|c|c|c|c|}
\hline \multirow[b]{2}{*}{ Variable } & \multirow[b]{2}{*}{ Standard Loading } & \multirow[b]{2}{*}{ Error } & \multicolumn{4}{|c|}{ Construct Reliability } & \multicolumn{3}{|c|}{ Variance Extracted } \\
\hline & & & $\sum_{\text {Loading }}$ STd. & $\begin{array}{c}\left(\sum \text { STd. }\right. \\
\text { Loading })^{2}\end{array}$ & $\sum$ Error & $\begin{array}{c}\text { CR } \\
\text { Value } \\
\end{array}$ & $\begin{array}{l}\text { Standard } \\
\text { Loading }^{2}\end{array}$ & $\begin{array}{l}\sum_{\text {Loading })^{2}}(\text { Std. } \\
\end{array}$ & $\begin{array}{c}\text { VE } \\
\text { Value }\end{array}$ \\
\hline \multicolumn{10}{|l|}{ Job Autonomy } \\
\hline OK1 & 0.68 & 0.54 & 2.09 & 4.37 & 1.53 & 0.74 & 0.46 & 1.47 & 0.49 \\
\hline OK2 & 0.61 & 0.63 & & & & & 0.37 & & \\
\hline OK3 & 0.80 & 0.36 & & & & & 0.64 & & \\
\hline \multicolumn{10}{|c|}{ Work Life Balance } \\
\hline WLB1 & 0.43 & & 4.34 & 18.84 & 2.23 & 0.89 & 0.18 & 2.52 & 0.53 \\
\hline WLB2 & 0.44 & & & & & & 0.19 & & \\
\hline WLB3 & 0.41 & & & & & & 0.17 & & \\
\hline WLB4 & 0.51 & 0.74 & & & & & 0.26 & & \\
\hline WLB5 & 0.46 & & & & & & 0.21 & & \\
\hline WLB6 & 0.72 & 0.48 & & & & & 0.52 & & \\
\hline WLB7 & 0.84 & 0.29 & & & & & 0.71 & & \\
\hline WLB8 & 0.53 & 0.72 & & & & & 0.28 & & \\
\hline \multicolumn{10}{|c|}{ Job Satisfaction } \\
\hline KK1 & 0.56 & 0.69 & 10.72 & 114.92 & 8.63 & 0.93 & 0.31 & 7.36 & 0.46 \\
\hline KK2 & 0.62 & 0.62 & & & & & 0.38 & & \\
\hline KK3 & 0.61 & 0.63 & & & & & 0.37 & & \\
\hline KK4 & 0.52 & 0.73 & & & & & 0.27 & & \\
\hline KK5 & 0.63 & 0.61 & & & & & 0.40 & & \\
\hline KK6 & 0.60 & 0.64 & & & & & 0.36 & & \\
\hline KK7 & 0.65 & 0.57 & & & & & 0.42 & & \\
\hline KK8 & 0.58 & 0.67 & & & & & 0.34 & & \\
\hline KK9 & 0.76 & 0.42 & & & & & 0.58 & & \\
\hline KK10 & 0.64 & 0.59 & & & & & 0.41 & & \\
\hline KK11 & 0.89 & 0.20 & & & & & 0.79 & & \\
\hline KK12 & 0.87 & 0.24 & & & & & 0.76 & & \\
\hline KK13 & 0.82 & 0.33 & & & & & 0.67 & & \\
\hline KK14 & 0.70 & 0.50 & & & & & 0.49 & & \\
\hline KK15 & 0.67 & 0.55 & & & & & 0.45 & & \\
\hline KK16 & 0.60 & 0.64 & & & & & 0.36 & & \\
\hline \multicolumn{10}{|c|}{ Organizational Comitment } \\
\hline KO1 & 0.90 & 0.20 & 6.13 & 37.58 & 3.13 & 0.92 & 0.81 & 4.89 & 0.61 \\
\hline $\mathrm{KO} 2$ & 0.91 & 0.17 & & & & & 0.83 & & \\
\hline KO3 & 0.85 & 0.29 & & & & & 0.72 & & \\
\hline KO4 & 0.93 & 0.13 & & & & & 0.86 & & \\
\hline KO5 & 0.81 & 0.34 & & & & & 0.66 & & \\
\hline KO6 & 0.56 & 0.68 & & & & & 0.31 & & \\
\hline KO7 & 0.53 & 0.72 & & & & & 0.28 & & \\
\hline KO8 & 0.64 & 0.60 & & & & & 0.41 & & \\
\hline
\end{tabular}

Table 2. Testing of the research model hypothesis

\begin{tabular}{llcl}
\hline Hypothesis & T- Value & Results \\
\hline H1 & There is an influence of job autonomy on work - life balance & 2.69 & Hypothesis is accepted \\
H2 & There is an influence of job autonomy on job satisfaction & 7.32 & Hypothesis is accepted \\
H3 & There is an influence of work-life balance on job satisfaction & 4.65 & Hypothesis is accepted \\
H4 & There is an influence work-life balance on organizational comitment & 5.78 & Hypothesis is accepted \\
H5 & There is an influence of job satisfaction on organizational comitment & 2.96 & Hypothesis is accepted \\
\hline
\end{tabular}




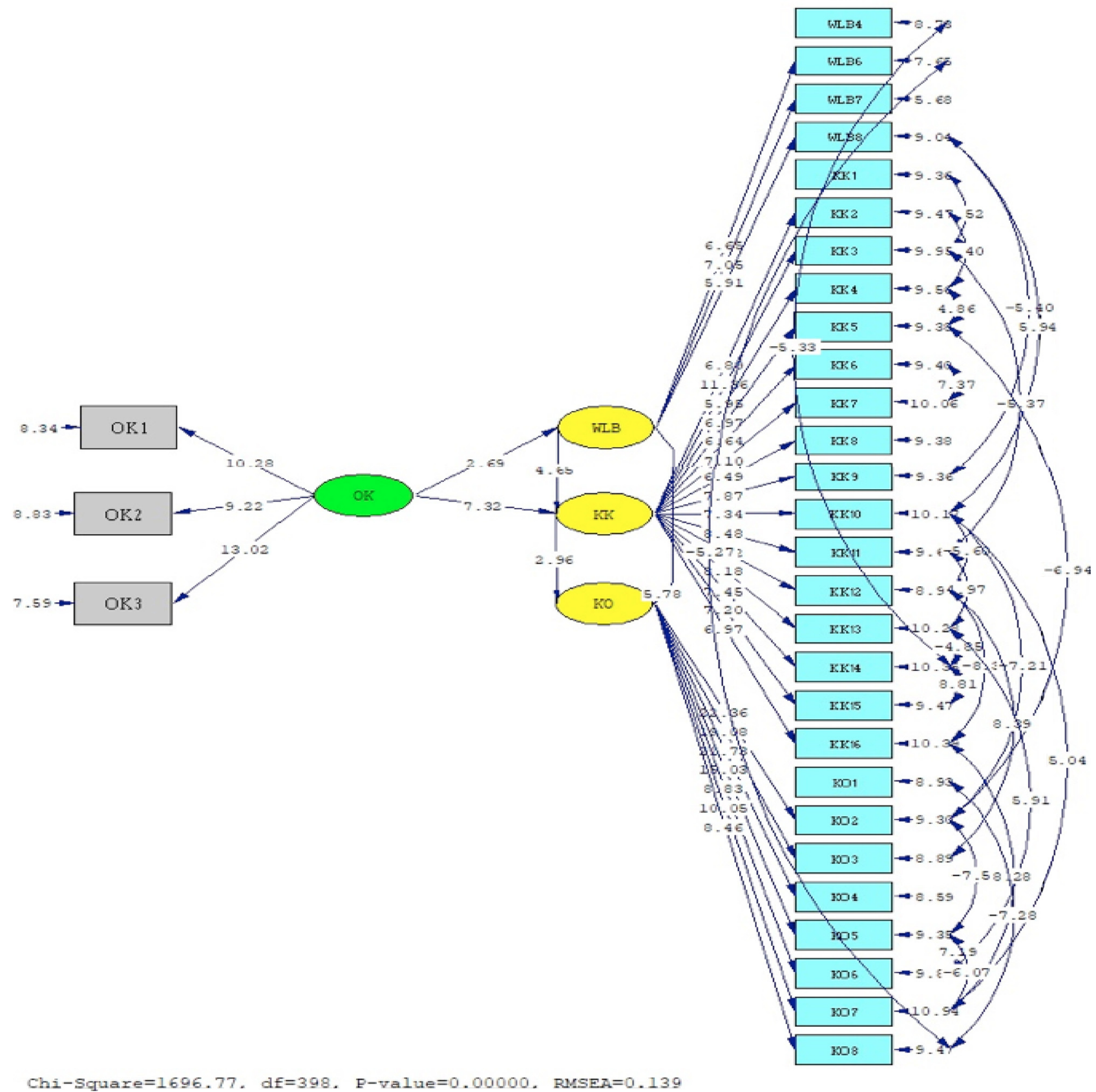

Figure 2. T-Value path diagram

In this study, some results showed that job satisfaction will increase organizational commitment in the life insurance industry. This means that a workplace that provides appropriate duties, a leader who encourages the performance of employees, and colleagues who establish high cooperation will have a positive impact on organizational commitment. This is supported by the statements of Rojuaniah (2017); Taurisa and Ratnawati (2012); Gunlu et al. (2010); and Meria (2018) which states that job satisfaction can increase organizational commitment .

\section{Managerial Implications}

This research aimed to find out the relationship of job autonomy and work-life balance with organizational commitment through employee job satisfaction in the life insurance industry. Like other companies, in the life insurance industry, employees work 8 hours a day, from 08:00 am to 05:00 pm, with 1 hour break time. Working in the life insurance industry, employees work to achieve the company's targets. Employees should also have good coordination and cooperation with almost all departments. Workload also becomes a common issue. In general, some life insurance industries have already 
taken into account the number of employees based on workload. However, in reality, there are certain times where employees have excessive workloads. Usually, this condition occurs at the end of the month, when the company is trying to achieve the targets. Employees have work overtime. This can sometimes be reasonable in achieving targets. This is why it is very important to have a work-life balance program implemented in a company, so the employees will have a balanced time between work and family. This work-life balance program is very important to improve job satisfaction for employees.

The managerial implication that can be proposed to increase organizational commitment through employee job satisfaction in the life insurance industry is using the dimensions of job autonomy and work-life balance used in this study. The first dimension is the autonomy of the working method. The manager should allow the employees to decide on how best to get the job done. This will make the employees more motivated in their work, to have job satisfaction, and commit to the company. The second dimension is the autonomy in the work schedule. The manager must trust and encourage the employees to get their work done. An employee should be able to manage his work so that he can get it done according to the time that is set. The third dimension is the autonomy of the working criteria. The manager must encourage and support the employees with the expertise to get the job done.

Furthermore, considering the work-life balance dimensions used in this study. The first dimension is the balance of time. Employees will be satisfied with their work when they can manage a balanced time for work, family, relatives and friends. The second dimension is the balance of engagement. Employees can manage their time when engaging in work and non-work roles. The third dimension is the balance of satisfaction. Employees who work in an office and work environment that supports activities will enjoy both work and personal life. This state will make employees highly committed to the company.

\section{CONCLUSIONS AND RECOMMENDATIONS}

\section{Conclusions}

The first result of this study showed that good work autonomy would improve employee work-life balance. Employees with the autonomy to make necessary decisions in their field of duty will make them feel trusted to manage time, both for work and for the family. Second, good work autonomy will improve employee job satisfaction. With this work autonomy, employees will be more motivated at work. Thus, they feel satisfied with their work. Third, a good worklife balance will increase employee job satisfaction. Employees with a work-life balance will increase their productivity because they are satisfied to work at the company. The fourth is that a good work-life balance will increase the organizational commitment of employees. Employees who have a good work-life balance will have more commitment to their place of work. The fifth is that good job satisfaction will increase the organizational commitment of employees. The higher the level of employee satisfaction, the higher the work commitment.

\section{Recommendations}

It is recommended that future research developments can add variables other than work autonomy and work-life balance that can improve job satisfaction and organizational commitment, such as leadership style and work culture. It is also suggested that future research can expand the scope of research, not only in the life insurance companies but also in the loss insurance companies, the re-insurance companies, and in other financial services industries such as in the banking industry.

The limitations of the study referred to some of the flaws in this study. This research only addressed to the variables of work autonomy, work-life balance, job satisfaction and organizational commitment. There was also possible that the respondents only filled based on the expected ideal conditions, not the actual ones. 


\section{REFERENCES}

Asepta UY, Maruno SHP. 2017. Analisis pengaruh work life balance dan pengembangan karir terhadap kepuasan karyawan PT Telkomsel, Tbk Branch Malang. Jibeka 11(1):77-85. https://doi. org/10.32812/jibeka.v11i2.64

Gulbahar, Amjad A, Kundi G, Qureshi Q, Akhtar R. 2014. Relationship between work-life balance \& organizational commitment. Research on Humanities and Social Sciences 4(5):1-7.

Gunlu E, Aksarayli M, Perçin NŞ. 2010. Job satisfaction and organizational commitment of hotel managers in Turkey. International Journal of Contemporary Hospitality Management 22(5):693-717. https:// doi.org/10.1108/09596111011053819

Hair JF, Black WC, Babin BJ. 2010. Multivariate Data Analysis: A Global Perspective. (Upper Saddle River, Ed.). Ed. ke-7. New Jersey: Pearson Education, Inc.

Hakim L, Septarini BG. 2014. Hubungan antara otonomi kerja dengan kebahagiaan kerja pada industri kreatif (relation of work autonomy with happiness at work in creative industry). Jurnal Psikologi Industri dan Organisasi 3(1):210 217.

Handayani A, Maulia D, Dian M, Nyoman MNA. 2018. Pengaruh otonomi kerja terhadap keseimbangan kerja-keluarga dengan komitmen peran. Seurune: Jurnal Psikologi Unsyiah 1(1):53-73. https:// doi.org/10.24815/s-jpu.v1i1.9924

Handoko H. 2000. Manajemen Personalia dan Sumber daya Manusia. Yogyakarta: BPFE-Yogyakarta.

Hudson. 2005. The case for work / life balance: Closing the gap between policy and practice: 1-39.

Malhotra NK. 2010. Marketing Research: An Applied Orientation. Ed. ke-6. US: Pearson.

Mauno S, Kinnunen U, Ruokolainen M. 2006. Exploring work- and organization-based resources as moderators between workfamily conflict, well-being, and job attitudes. Work and Stress 20(3):210-233. https://doi. org/10.1080/02678370600999969

Meria L. 2018. Pengaruh konflik pekerjaan keluarga dan kepuasan kerja terhadap komitmen organisasional. Jurnal Ekonomi 9(2):204-212.

Meyer JP, Allen NJ, Smith CA. 1993. Commitment to organizations and occupations: Extension and test of a three-component conceptualization. Journal of Applied Psychology 78(4):538-551. https://doi.org/10.1037//0021-9010.78.4.538
Pearson A, Pearson JM, Griffin C. 2009. Innovating with technology: the impact of overload, autonomy, and work and family. Journal of Information Technology Theory and Application (JITTA) 9(4).

Poluan AR. 2018. Pengaruh work-life balance, beban kerja dan gaya kepemimpinan terhadap kinerja pegawai PT. Bank Negara Indonesia (PERSERO) TBK, Kantor Cabang Manado. Jurnal Riset Bisnis Dan Manajemen 6(4).

Rene R, Wahyuni S. 2018. Pengaruh work-life balance terhadap komitmen organisasi, kepuasan kerja, dan motivasi kerja terhadap kinerja individu pada karyawan perusahaan asuransi di Jakarta. Jurnal Manajemen Dan Bisnis Sriwijaya 16(1):53-63. https://doi.org/10.29259/jmbs.v16i1.6247

Robbins SP, Judge TA. 2013. Organizational Behavior. Ed. ke-17. US: Pearson. https://doi.org/10.1007/ BF01148546

Robbins ST, JudgeTA, HashamES. 2012. Organizational Behavior: Arab World Edition. Retrieved from http://www.pearsonmiddleeastawe.com/pdfs/ OB-SAMPLE.pdf

Rojuaniah. 2017. Kepuasan kerja sebagai pendorong komitmen organisasional dan Organizational Citizenship Behavior (OCB). Jurnal Ekonomi 8(2):222-231.

Saad R, Sumaiti A. 2010. Faculty of business msc in project management the work life balance and job satisfaction in oil and gas organisations in the uae context. Retrieved from https://bspace. buid.ac.ae/bitstream/1234/320/1/70060.pdf

Sakthivel D, Jayakrishnan J. 2012. Work life balance and organizational commitment for nurses. Asian Journal of Business and Management Sciences 2(5):2047-2528.

Sopiah. 2008. Perilaku Organisasi. Yogyakarta: ANDI.

Stefanovska-Petkovska M, Petrovska I, Bojadziev M, Schaeffer I, Tomovska-Misoska A. 2019. The effects of organizational culture and dimensions on job satisfaction and work-life balance. Montenegrin Journal of Economics 15(1):99-112. https://doi.org/10.14254/18005845/2019.15-1.8

Sugiyarti G, Meiliana TW. 2018. Analisis otonomi kerja terhadap komitmen organisasi dan kepuasan kerja dengan peran moderasi budaya organisasi pada pedagang kaki lima di Perumnas Tlogosari Kota Semarang. Serat Acitya: Jurnal Ilmiah 7(2):90-96. 
Suwarno, Priansa DJ. 2011. Manajemen SDM dalam Organisasi Publik dan Bisnis. Bandung: Alfabeta.

Taurisa CM, Ratnawati I. 2012. Analisis pengaruh budaya organisasi dan kepuasan kerja terhadap komitmen organisasional dalam meningkatkan kinerja karyawan. Jurnal Bisnis Dan Ekonomi (JBE) 19(2):170-187. https://doi.org/10.24912/ jm.v19i2.129
Varatharaj, Vasantha. 2016. Work life balance a source of job satisfaction - an exploratory on the view of women. Journal of Research in Marketing and Entrepreneurship 18(2):232-247. https:// doi.org/10.1108/JRME-04-2015-0024

Wenno MW. 2018. Hubungan antara work life balance dan kepuasan kerja pada karyawan di PT PLN Persero Area Ambon. Maneksi 7(1):47-54. https://doi.org/10.31959/jm.v7i1.86

Wibowo. 2011. Manajemen Kinerja. Jakarta: Rajagrafindo Persada. 